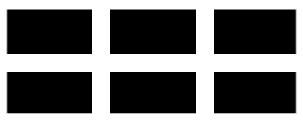

THE WILLIAM DAVIDSON INSTITUTE

AT THE UNIVERSITY OF MICHIGAN BUSINESS SCHOOL

\title{
How Much Restructuring did the Transition Countries Experience? Evidence from Quality of their Exports
}

\author{
By: Yener Kandogan
}

William Davidson Institute Working Paper Number 637

January 2004 


\title{
How Much Restructuring did the Transition Countries Experience? Evidence from Quality of their Exports
}

\author{
By \\ Yener Kandogan \\ University of Michigan-Flint
}

Running Title: Extent of Restructuring

Correspondence Address:

School of Management

University of Michigan-Flint

303 E. Kearsley

Flint, MI 48502

Phone: (810) 2376675

Fax: (810) 7623282

Email: yener@umich.edu 


\title{
How Much Restructuring did the Transition Countries Experience? Evidence from Quality of their Exports
}

\begin{abstract}
The increase in exports to market economies is a good sign, but it is not conclusive about the extent of restructuring of production technologies experienced in transition countries. This paper explores the source of the increase with an analysis of their exports' quality, interprets the results for the extent of restructuring, and discusses the potential factors behind them. Changes in factor intensity and unit values of both CEEC and CIS exports in different manufacturing sectors during 1992-1999 are analyzed. Although CEEC are in a significantly better position than CIS due to Europe Agreements, there is still large number of products with structural problems in CEEC. Insufficient FDI, the OPT in the Europe Agreements, and not fully exploited human capital are suggested as possible factors.
\end{abstract}

JEL Classification: F14, F15, O19, P27

Keywords: Unit values, Restructuring, Eastern Europe, Commonwealth of Independent States, Europe Agreements. 


\section{INTRODUCTION}

The literature before the collapse of socialism provides numerous accounts for the technological backwardness in Eastern Europe: van Brabant (1988) and Bogomolov (1987) point out that Eastern European manufactured goods lacked sufficient quality and technical sophistication to be marketable in western markets. Treml (1981) identifies a similar situation in the Soviet manufactured goods and machinery. The US-imposed embargo on exports of strategic and high technology goods to communist economies in 1947 can be counted as one of the important causes for this situation (van Brabant, 1980). However, the trade block formed in response among socialist countries in 1949, the Council for Mutual Economic Assistance (CMEA), where there were no incentives for competition or innovation, is considered by many as the primary reason for the low quality of Eastern European products.

After the fall of socialism, these countries have undergone a series of reforms to restructure their production technologies. Most noteworthy reform towards this goal is the extensive efforts to liberalize their international trade. Beside the unilateral removal of quantitative trade barriers, almost immediately after the collapse of CMEA in 1991, 10 Central and Eastern European countries (CEEC) signed the Europe Agreements with the European Union (EU). Five out of 12 Commonwealth of Independent States (CIS) formed a customs union in $1994{ }^{1}$

Initially, the opinion in Europe was that this rapid trade liberalization would not succeed. They would not be able to export their products to market economies because their products were of such poor quality to be marketable internationally. Furthermore, their production technology was largely resource-intensive due to subsidized resource 
imports from Russia, which made their capital obsolete after the breakup of CMEA. They needed to restructure their production technology.

However, contrary to expectations, there has been a considerable reorientation of exports towards the EU, especially in CEEC, away from the former partners in CMEA. The increase in trade with market economies is a good sign, but it is not conclusive about the extent of restructuring experienced in transition countries. The important question is the source of the increase in trade with these non-traditional partners. The increase could be a result of intensive margin, where there is quality and thus price increase in the products, or extensive margin, where a larger quantity of a larger set of goods is exported (Hummels and Klenow, 2002). The answer to this question will help determine the extent of restructuring achieved, and thus the success of transitional reforms.

At this point, a distinction should be made between restructuring and specialization. Within the context of transition countries, restructuring implies improving product quality by upgrading the production technologies. Specialization implies changes in the quantity of exports in response to liberalization. As trade barriers are removed, the composition of exports changes to reflect the comparative advantages. Depending on the relative factor endowments, this leads to specialization in certain industries. Even if a country specializes in low-skilled labor or resource intensive industries, it could still experience restructuring. This can be done by gradually improving the production technology and thus the quality of the products in that industry.

Previous work on this area concentrated primarily on the most advanced countries in CEEC, and covered the time period of 1989-94. In the earliest analysis, Drabek and Smith (1995) found that the unit values of EU imports from CEEC have fallen. 
Analyzing 1989-92, Brenton and Gros (1997) found little evidence for product upgrading. Although Landesmann and Burgstaller (1998) argued that CEEC exports are concentrated on lower quality products, they indicated that the quality gap between the EU, and Hungary, Poland, Slovenia and the Czech Republic narrowed during 1989-94, and the gap with Bulgaria and Romania widened.

This paper analyses the changes in the quality of exports from all 22 transition countries, interprets the findings to determine the extent of restructuring, and discusses the potential factors behind it. The focus is on only the manufacturing exports (SITC 5-8) at product level during 1992-99, which excludes early years of transition with turbulent macroeconomic problems. ${ }^{2}$ The analysis is restricted to exports to market economies only. The reasons are numerous: Most importantly, restructuring of production technologies is needed to be able to export especially to market economies. Exports to formerly socialist partners could still be under the influence of CMEA arrangements in practice, despite its formal abolishment. Lastly, developed or developing, market economies are becoming increasingly important partners for transition countries. ${ }^{3}$

Although this analysis should not be considered as a formal empirical test of Grossman and Helpman (1991), the approach of this paper is influenced by their quality ladders concept in economic growth. Accordingly, the middle income South competes with the industrialized North by imitating their innovations. In the South, progress is achieved by importing product designs and production methods of the North. If the factor endowment conditions permit, the South can earn rents due to lower manufacturing costs. In the wake of loss of profit potential, the North designs the next generation higher quality product and methods. Eventually, this product is imitated in the South, too. 
Overall, a gradual increase in quality is observed for the products manufactured in the South. Transition countries very nicely represent the South in this theory: High levels of FDI provide a channel for importing product designs and methods; Abundance of human capital, and its low cost make imitation feasible and profitable, respectively.

The rest of the paper is organized as follows. In section 2, changes in factor intensity of exports are analyzed to get an idea about changes in the quality of their products. CEEC and CIS countries are analyzed separately for comparison. Section 3 briefly discusses the limitations of analyzing factor intensity of exports in this context, and some issues related to the use of unit values to represent quality. In this section, changes in quality and their implications on economic restructuring are discussed in detail. Then, changes in aggregate unit values, number of products under quality improvement are analyzed. Lastly, based on changes observed in unit values and trade balance, products are categorized into those with structural problems, with deficit in price competition, as well as those under successful price or quality competition. Section 4 interprets of the results by relating them to the scope of trade liberalization agreements, the FDI inflows, and the abundance and the cost of factor endowments such as human capital.

\section{FACTOR INTENSITY OF EXPORTS}

A traditional way to find out about the quality of goods is to look at the production technology. Changes in the factor content of production reveal the amount of technological improvement and thus the extent of restructuring. Under CMEA, the factor used intensively in transition countries' exports was resource. Thus, a move towards human and physical capital intensive production implies significant improvement of the 
production technology. To analyze the factor content of the transition countries' exports to market economies, this paper uses the quality classification of Wolfmayr-Schnitzer (1998). Accordingly, the quality of production increases with the intensity of factors in the following order: Resource intensive, human capital intensive- low technology, labor intensive, human capital intensive-medium technology-labor intensive, human capital intensive-medium technology-capital intensive, human capital intensive-high technologylabor intensive, and human capital intensive-high technology-capital intensive. SITC codes of products in each factor content category are given in Appendix 1.

Figures 1 and 2 give shares of these factor content categories in exports of CEEC and CIS to market economies each year during the period of 1992-99. There are clear differences between the factor content of CEEC and CIS exports. In CEEC, the share of resource intensive exports is much smaller, and it has a downward trend. This downward trend started late in 1995 in Bulgaria and Romania. In contrast, the share of resource intensive products in CIS exports was very large, ranging from 53\% in Moldova to $97 \%$ in Tajikistan in 1992, except Armenia (16\%). Seven CIS countries experienced a decrease in the share of resource intensive exports. The decreasing trend was reversed in Kyrgyzstan in 1996 and in Tajikistan in 1999, coinciding with their inclusion in the CIS customs union. There was no decreasing trend in other members of CIS customs union, such as the Russian Federation and Kazakhstan.

The trend in the share of top 4 high quality categories exhibit differences between CEEC and CIS as well. All CEEC, except for relatively labor abundant countries (Bulgaria, Romania, Latvia, and Lithuania) experienced substantial increases in the share of these four high quality categories. These four countries experienced increases in the 
share of labor intensive exports in these four countries, as a result of Outward Processing Trade (OPT) arrangements in the Europe Agreements for labor intensive sectors of clothing and footwear (SITC 841, 842, 851). ${ }^{4}$ Shares of top 4 high quality categories ranged from $9 \%$ to $17 \%$ in these four countries in 1999 . It was $29 \%$ in Poland, $51 \%$ in Hungary, and between $39 \%$ and $46 \%$ in other CEEC. In the CIS, a decreasing trend in the share of these categories was more common, except in Kazakhstan, Belarus, Azerbaijan, and Kyrgyzstan. In 1999, their share was much smaller than those for CEEC.

\section{IMPLICATIONS OF CHANGES IN THE UNIT VALUE OF EXPORTS}

Although examining the factor intensity of manufacturing exports gives a general idea about the extent of restructuring, not much can be inferred about the response of individual sectors to competition from market economies due to the amount of aggregation involved. Furthermore, the analysis in the previous section is based on shares of export volumes of products. The observed changes could very well be a result of an increase in quantity, that is, specialization in certain industries according to comparative advantages, as well as restructuring of production technologies, measured by increases in quality. To get a better idea about restructuring, changes in quality must be measured for individual products, rather than an analysis of shares of export volumes. Unit values provide a better and more frequently used tool to measure quality changes due to technological improvements.

The unit value of exports is defined as the dollar value of exports in a given commodity category divided by its physical weight. Units can be weight in tons, volume in cubic meters, area in square meters, or even length in meters. Thus, the unit value 
might be different from unit price. Thanks to the work of Lipsey (1963), and Kravis and Lipsey $(1971,1974)$, it has been known that unit value indices can be poor substitutes for price indexes. Several reasons have been put forward to explain this inadequacy of unit values: First of all, changes in unit values might be a result of not only price changes but also the change in quality of products. According to Enoch (1978), Maciejewski (1983), and King (1993), the most commonly cited reason is that a change observed in unit values may not necessarily be a result of an underlying price change, but simply a reflection of changes in the composition of goods within a class of products: The unit value for a class of products will change if the quantity of a low price product in that class changes relative to the quantity of high price products or vice versa. Furthermore, in different countries unit values are combined with different weights, and different indexnumber formulae are used. However, the unit values can still reflect the price if the quantity unit in which output is measured is the same as the unit of the input, and material is the most important input. For example, since iron is the primary material used in steel, the unit value of steel reflects its price.

According to Aiginger (1998), Landesmann and Burgstaller (1998), rather than the price, a higher unit value reflects higher quality. The reasoning is two-fold: If the products are similar, the prices that consumers are willing to pay must lie in differences in the consumers' perception of the quality of the products. Furthermore, higher quality products embody a greater proportion of factors that do not make a corresponding contribution to the weight of the product. This argument coincides with the previous analysis where products that intensively use human and physical capital are assumed to have higher quality. When there are different products in the same category, unit values 
reflect differences in the value added. Differences in the value added reflect the quality differences, arising from better skills or technology. For example, differences in the unit value of watches are signs of quality differences.

Aiginger (1998) argues that as a country's output structure moves up the quality ladder, this is reflected in an increase in the unit value of that country's aggregate exports of manufactures. A country with higher unit values supplies a higher quality of the same product or different products from a higher priced segment. Consequently, differences in the unit value of aggregate exports can be taken as an approximation of the relative quality difference. Aggregation, which seems to be a disadvantage in comparison of pure prices, proves to be an advantage in comparing the quality of exports at different points in time or across countries.

When competing internationally, the technologically superior partner retains its competitiveness with increasing quality, and the inferior one becomes more competitive by engaging in price competition. Thus, transition countries can engage in either price competition and sell their existing products at lower prices without restructuring their production technologies, or try to improve the quality of their products by restructuring. The difference is that technological restructuring cannot happen instantaneously, but price competition can. ${ }^{5}$ Given the initial conditions, transition countries are expected to initially engage in more price competition than quality improvement. They can overcome this initial disadvantage through changes in the economic environment away from innovation-averse culture towards one that encourages innovation and by importing product designs and production methods, and move up the quality ladder as suggested in Grossman and Helpman (1991). Thus, lower quality products gradually disappear to the 
extent of restructuring. This discussion implies U-shaped aggregate unit values: In the early periods of transition, countries engage in price competition, and the unit values decrease. As time passes, there are increases in the quality of some products and/or the proportion of products with higher quality increases due to restructuring. Consequently, the aggregate unit value starts increasing after some point. Of course, given a time period of analysis, depending on where each country is in restructuring, one may observe decreasing aggregate unit values if restructuring has not been significant so far, or increasing aggregate unit values if quality improvement due to restructuring has been more dominant than price competition.

This is what is observed in Figure 3, where aggregate unit values for each sector (1digit SITC categories) are plotted for each transition country. In the chemicals sector, price competition is widespread in CEEC, whereas except for two countries, CIS experienced increases in unit values. Quality improvement is common in other sectors for CEEC: In the manufacturing sector, all CEEC experienced increases in the unit values. In the machinery and miscellaneous manufacturing sectors, the unit values increased for the majority of CEEC. Hungary experienced decreases in both sectors. Slovenia experienced a decrease in only miscellaneous manufacturing. In the machinery sector, Slovenia and the Czech and Slovak Republics eventually turned the decreasing trend up. Decreasing unit values are much more common in CIS. The U-shaped unit values are especially common in the machinery sector. The manufacturing sector is the sector where the majority of the CIS countries experienced increasing unit values.

Apart from aggregate unit values, an analysis of the unit values in each product category (4-digit level SITC categories) is also necessary: Table 1 gives the number 
traded products under quality improvement to get an idea about the extent of restructuring in each transition country in each of SITC 5-8 sectors. ${ }^{6}$ If there is an increasing trend in the unit value for a product category for the whole time period, it is considered to be already under quality improvement in 1993. Each year, the products that reverse the decreasing trend to an increasing trend are added to the list of products under quality improvement. The difference between CIS and CEEC is once again striking. For all CEEC, more than $30 \%$ of traded products were under quality improvement in 1993 , and almost all CEEC surpassed $40 \%$ by the end of 1999 , led by the Czech Republic, and Poland. Although started at low levels, Slovenia, and Hungary had the fastest increase in the number of products under quality improvement. ${ }^{7}$ Baltic States of Lithuania, Estonia and Latvia started at the lowest level, and had the lowest rate of increase. In contrast to CEEC, in all CIS except European CIS countries (Russia, Ukraine, and Belarus) and Kazakhstan, the percentage of traded products under quality improvement remained below $15 \%$ for the all period of analysis. In the first three countries, the rate of increase was comparable to that in CEEC. Kazakhstan, Georgia, and Moldova had smaller increases. The increase in other CIS can be considered negligible. When all CIS and CEEC are considered together to observe differences across sectors, it can be seen that the machinery sector (SITC-7) performed the worst in CIS, but the best in CEEC. The chemicals sector (SITC-5) did not perform well in both groups of countries. Especially in CEEC, this sector's performance was significantly different than other sectors.

While increasing unit values is an indicator of quality competitiveness for some industries, for others, decreasing unit value can be an indicator of price competitiveness. Put differently, although decreasing unit values does not imply restructuring, it is not 
always a sign of distressed trade from structural problems. To decide if there are structural problems that need to be addressed, the performance of trade balance should be considered: Deteriorating trade balance can imply structural problems, or deficit in price competition depending on the direction of change in unit values. In a static analysis, Aiginger (1997) partitions products into four categories: Accordingly, if products are homogenous, price competition is important and unit values reflect average costs. In this case, the country with lower costs will be net exporter. This is the case of successful price competition. In contrast, trade deficit together with lower unit values implies distressed trade resulting from structural problems. If product innovation is important, the unit values will be higher than the costs, and will reflect technological superiority. If a country is a net exporter, despite higher unit values, this must be due to successful quality competition. Finally, a deficit in price competition occurs, when a country has higher unit value and suffers from a trade deficit. In this case, the country has lost its price competitiveness due to high production costs.

In the absence of unit values of exports from partners for comparison, extending this static analysis across time allows similar categories: When trade balance is improving, increasing unit values is a sign of quality competition, whereas decreasing unit values is a sign for price competition. Consequently, when trade balance deteriorates, decreasing unit values implies structural problems, and the country loses its price competitiveness if unit values increase.

Table 2 gives the number of traded products that fall under the competitiveness categories described above for each CEEC and CIS. ${ }^{8}$ The picture is gloomy for both CEEC and CIS, but much better for CEEC. In 1999, at least a quarter of products still had 
structural problems in all CEEC, smallest in the Czech Republic, Bulgaria, Romania, Poland and Hungary. The situation is the same for Russia, and Ukraine, but much worse in other CIS ranging from $54 \%$ in Belarus to $96 \%$ in Turkmenistan. The percentage of products where CEEC is losing its price competitiveness is also rather high, from $25 \%$ in Latvia to about $40 \%$ in Poland. A fewer proportion of products is in this category in CIS. Products that transition countries are competitive by either price or quality are much higher in CEEC than in CIS. The proportion ranges from $20 \%$ to $40 \%$, where the majority is under quality competition for almost all CEEC. All CIS, except for Russia, Ukraine and Belarus, are competitive in less than $15 \%$ of the products. Competitiveness in these three countries is more or less comparable to CEEC. When analyzed sector by sector, it can be seen that manufacturing sectors SITC 6 and 8 are the most competitive sectors for both CEEC and CIS, and the chemicals sector (SITC-5) is the least competitive sector. Largest proportion of structural problems was in the chemicals sector.

\section{INTERPRETATION OF THE RESULTS}

Overall, CEEC countries performed much better than the CIS countries by the end of 1999. Considering the period of analysis, these results are partly consequences of the liberalization agreements. Table 3 gives the years of substantial unilateral removal of quantitative barriers, and the partner and dates of major liberalization agreements signed by transition countries. The Europe Agreements forced CEEC to compete with market economies, where CEEC had to restructure the production technology to be able to export. On the other hand, the CIS customs union was an attempt to preserve the status quo under CMEA. It does not encourage restructuring since it does not encourage trade 
with market economies. The increase in trade of resource-intensive goods in CIS customs union countries is a direct result of this. The effects of partner and date of liberalization are reflected into the correlation coefficients with the percent of products under structural problems. The coefficient is significant and negative for a dummy for CEEC (-0.7), implying that CEEC have significantly lower structural problems. It is insignificant and positive for a dummy for the CIS customs union members (0.19). Furthermore, the calculations show that the earlier the liberalization starts, the lower the percentage of products with structural problems. The coefficients are 0.74 and 0.73 , with dates of removal of quantitative barriers, and dates of liberalization agreements, respectively.

CEEC's success is also explained by the theory of Grossman and Helpman (1991). Accordingly, in order to improve the production technology, a country should first import the product designs and production methods, imitate them, and have lower costs of production to profitably export it. FDI is certainly one channel for obtaining design and methods, and transition countries certainly have the human capital to imitate, and low costs to make a profit. The amounts of cumulative FDI during 1988-99 are given in Table 3 , as well as three different measures of human capital, and monthly wages at the beginning of the period of analysis. CEEC countries have received the largest FDI among all emerging markets, have lower costs of labor and levels of human capital that are comparable to developed market economies, if not higher. Furthermore, Prosi (1998) argues that technology transferred by FDIs meet the factor proportions and technological skills of more advanced economies, not those of labor intensive economies. These factors combined together caused them to perform much better than the CIS as can be seen from correlation coefficients ${ }^{9}$. The coefficient between the percent of products with structural 
problems, and the amount of cumulative FDI is significant and negative $(-0.53)$. The coefficient with measures of human capital are all negative, but only significant for the education index (-0.46). Contrary to expectations, the coefficient with wages is significant, and negative. This is probably due to the fact that in all transition countries analyzed the wage rate is only a fraction of rates in developed market economies. As long as there is a wide wage gap, the restructuring will be more significant in countries that have higher FDI, and human capital.

However, despite their success relative to CIS, CEEC have also underperformed. There is still a lot of restructuring needed in CEEC, ranging from $26 \%$ to $56 \%$ of the products. Simple tariff cuts by the Europe Agreements are apparently insufficient to stimulate massive structural changes. Given their factor abundance relative to the EU, the Europe Agreements forced some CEEC to specialize in labor intensive low quality products. Although Martin (1998) considers this potential for Maquiladora Syndrome unlikely for the Czech Republic, Poland and Hungary, substantial increases in exports of labor-intensive products from Bulgaria, Romania, Latvia and Lithuania found in this paper should be noted with caution. In this context, it can be said that largely reported high skill in some CEEC is either overestimated or not yet exploited. Rosati (1998) proposes lack of capital as the leading cause. FDI was high, but considering how obsolete their capital was right after the fall of socialism, it is apparently not high enough.

\section{CONCLUSIONS}

There has been considerable amount of increase in the exports of transition countries to market economies, especially for the CEEC. This paper analyzed the quality of their 
exports to see if product upgrading was the reason for the increase in trade, and to what extent this reorientation was a consequence of restructuring of production technologies. For this purpose, the manufacturing exports of 22 transition countries in Central and Eastern Europe, and Central Asia to 28 developed or developing market economies during 1992-1999 were examined.

The changes in quality are first analyzed with an examination of the factor intensity of exports. It is observed that the share of exports of resource-intensive products have been decreasing in both CEEC and CIS. However, this legacy of socialism is still quite significant in CIS countries, where the share is very high. Interestingly, the only CIS countries with increasing shares are the members of the CIS customs union. The share of human capital intensive products is high and increasing for CEEC, whereas it is decreasing for CIS. The only exceptions in the CEEC are Bulgaria, Romania, Latvia and Lithuania, where the share of labor intensive products is increasing.

Although these observations are interesting, they could be a consequence of increasing quantity due specialization according to comparative advantages. Therefore, an analysis of unit values is carried out. A U-shaped pattern in aggregate unit values is observed, which is a result of initial price competition followed by quality improvement. When products are analyzed individually, it is found that $40 \%$ of exports of most CEEC countries were under quality improvement. Baltic States and European CIS countries of Russia, Ukraine and Belarus performed relatively worse. At most $15 \%$ of other CIS countries' exports were under product improvement by 1999 .

Although decreasing unit values does not imply restructuring of production technologies, it could be a result of successful price competition, and not distressed sale 
due to structural problems. To differentiate between these two possibilities, a dynamic version of the approach in Aiginger (1997) is applied. A gloomy picture resulted for both CEEC and CIS. Although the situation in CEEC was significantly better than CIS, more than $25 \%$ of products still had structural problems by the end of 1999 . Russia and Ukraine performed comparable to CEEC. In other CIS, the percentage of products with structural problems ranged from $50 \%$ to $95 \%$. Overall CEEC was much more competitive in either price or quality than the CIS countries.

These observations are in conjunction with the quality ladders in economic growth theory of Grossman and Helpman (1991). To restructure the production technology, a country should import the product designs and methods. High levels of FDI in the CEEC provided a channel. The country should be able to imitate the products. Human capital levels in CEEC, comparable to developed economies, made this possible. Finally, there should be lower costs of production. Significantly lower wages in all transition countries made this whole process profitable. The correlation coefficients between the percent of products under structural problems, and these factors showed support for this theory. 


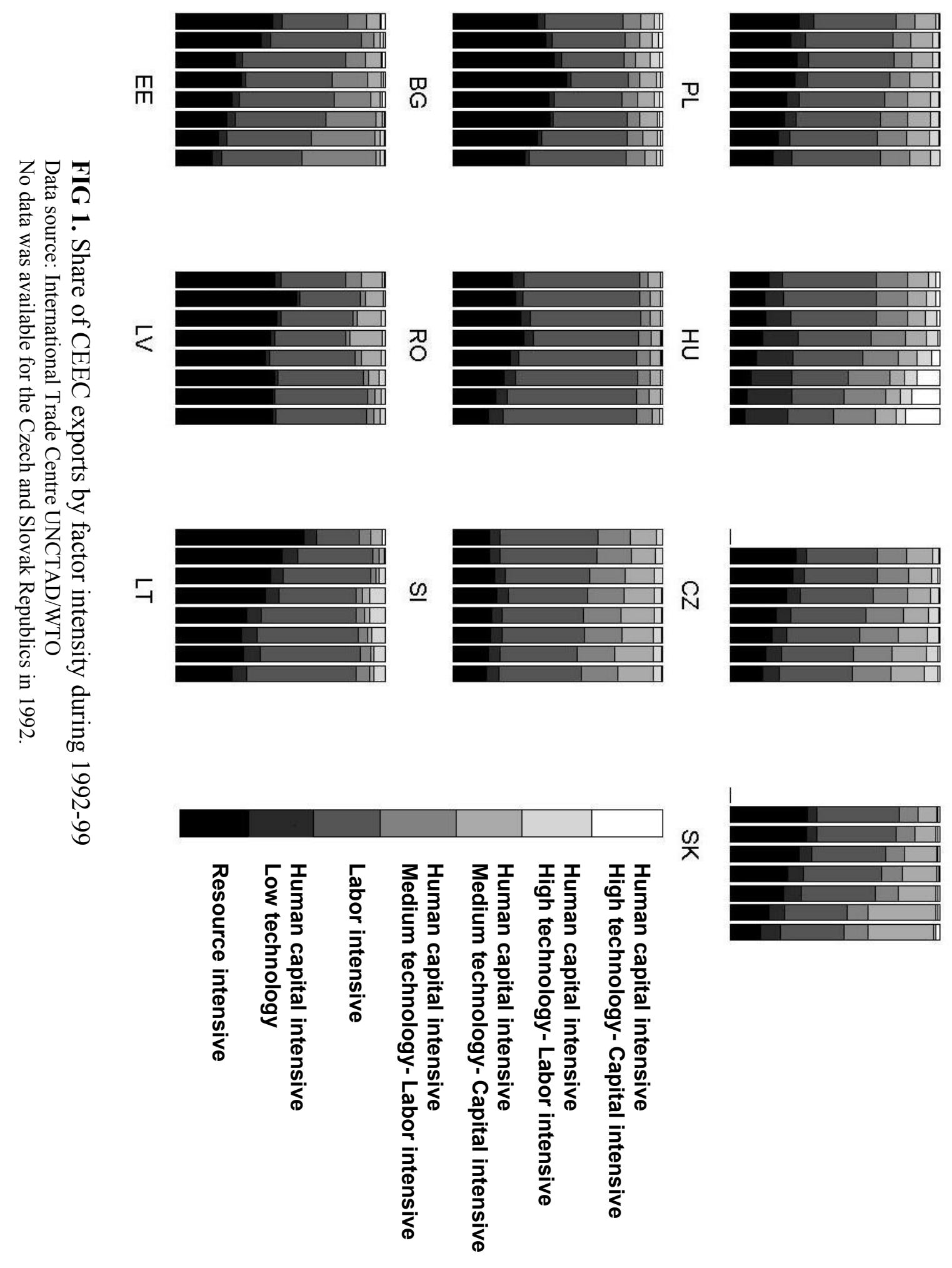


William Davidson Institute Working Paper 637

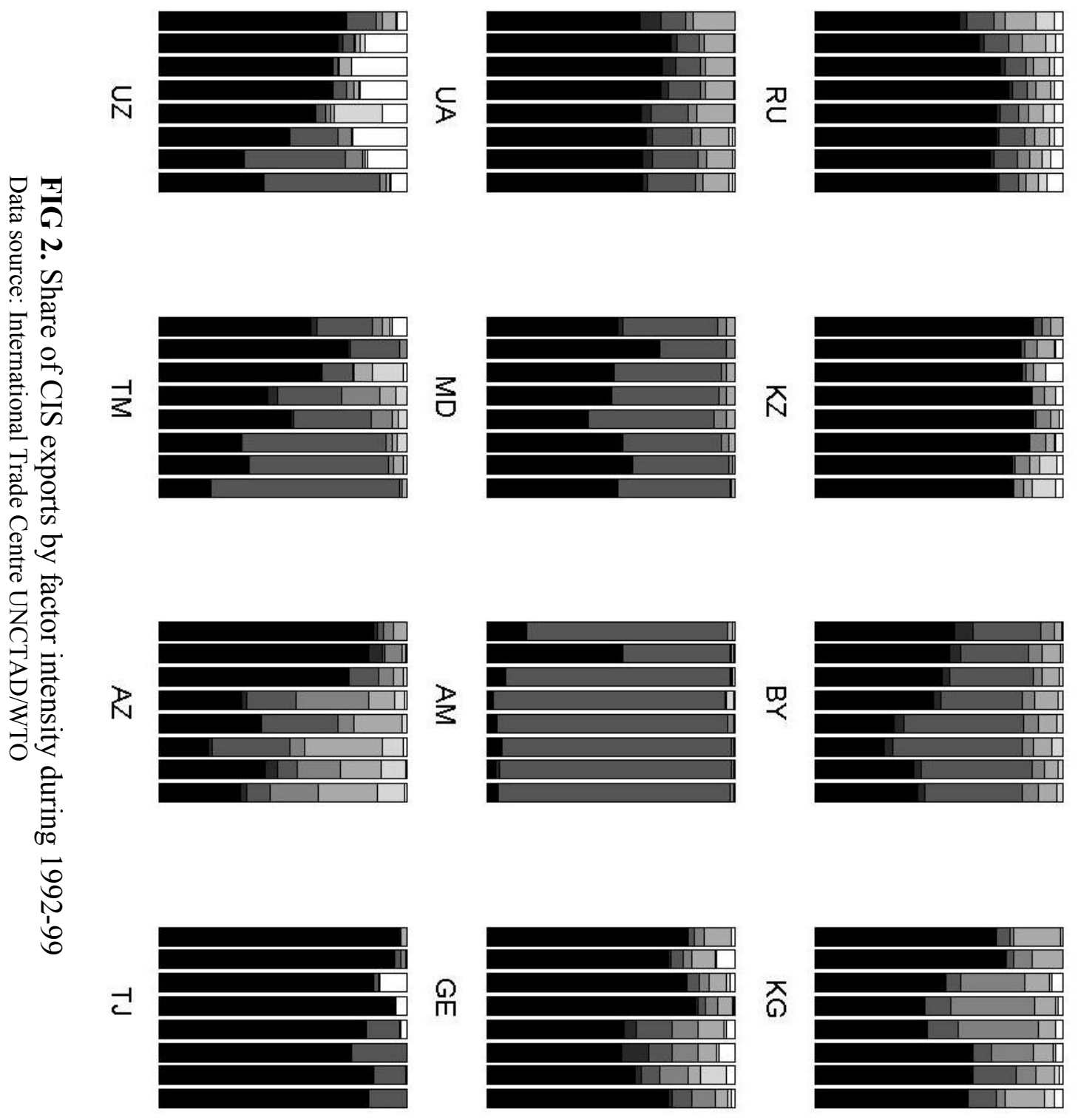



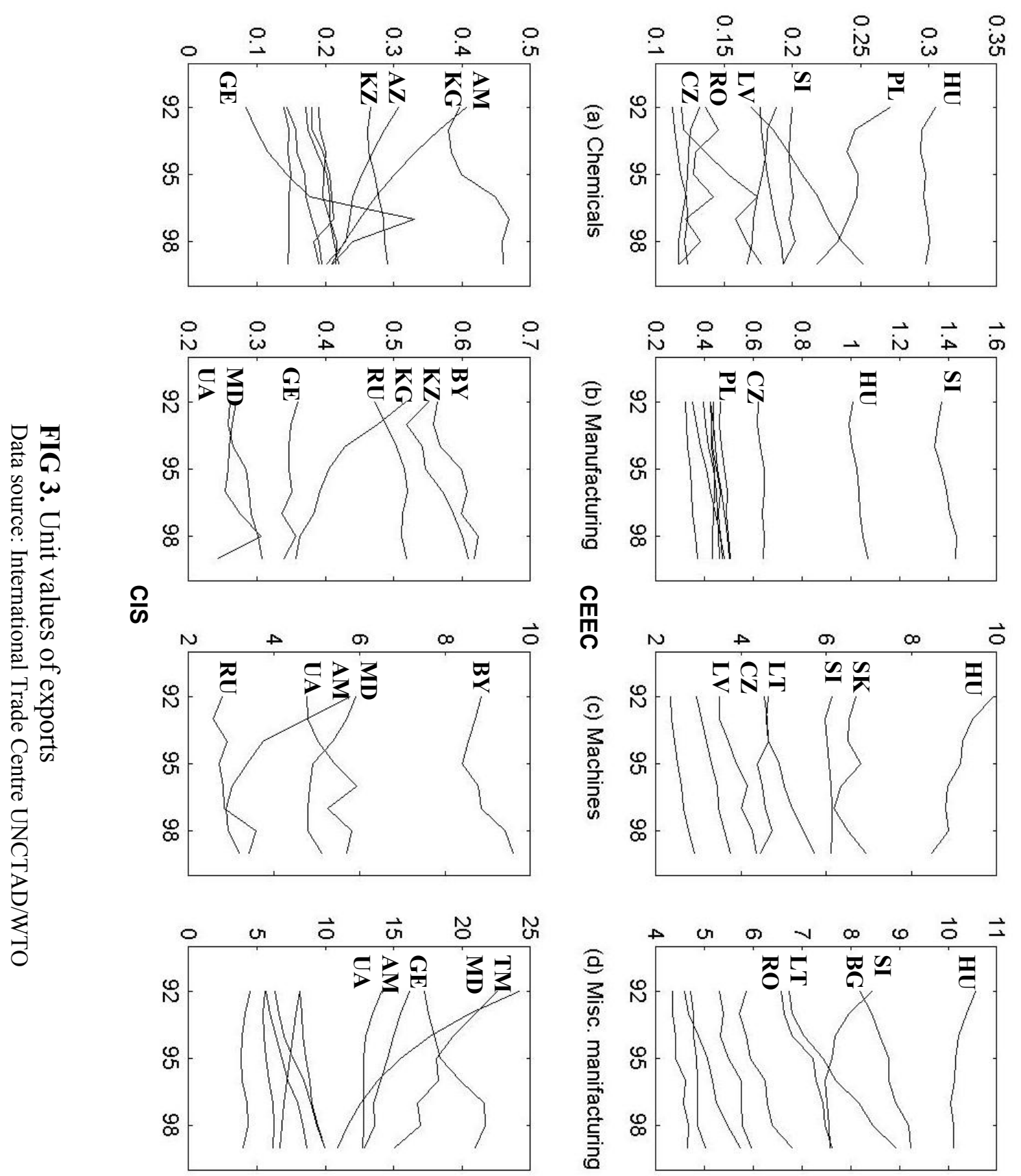


\begin{tabular}{|c|c|c|c|c|c|}
\hline Country & Chemicals & Manufacturing & Machinery & Misc. Man. & Total \\
\hline $\mathrm{BG}$ & $38-60 \quad(98)$ & $77-120(182)$ & $60-91 \quad(142)$ & $46-64 \quad(98)$ & $221-335(520)$ \\
\hline $\mathrm{CZ}$ & $34-57(110)$ & $88-130$ (209) & $113-149(186)$ & $61-87(118)$ & $296-423(623)$ \\
\hline EE & $10-18 \quad(80)$ & $68-86 \quad(162)$ & $54-67$ & 44-52 (99) & 472) \\
\hline $\mathrm{HU}$ & $30-58(107)$ & $83-128(206)$ & $67-103(16$ & $38-67(113)$ & \\
\hline LV & $13-24 \quad(79)$ & $55-67 \quad(15$ & & & \\
\hline & $1 \quad(68)$ & $67-$ & & $(1$ & \\
\hline PL & $29-52(114)$ & $100-145(205)$ & $92-135$ (1 & & \\
\hline RO & $26-40 \quad(90)$ & $84-1$ & $77-1$ & & \\
\hline SK & $36-46(101)$ & $79-1$ & & & \\
\hline SI & $26-51(102)$ & $81-127(205)$ & $70-106(1$ & $34-60(114)$ & $211-344(588)$ \\
\hline & $\begin{array}{ll}0-0 & (52) \\
\end{array}$ & & & $\begin{array}{ll}3-3 & (76) \\
\end{array}$ & $\begin{array}{ll}7-8 & (328)\end{array}$ \\
\hline A & (82) & $6-12$ & & $(90)$ & $15-26 \quad(453)$ \\
\hline B & $15-27 \quad(88)$ & $42-60 \quad(15$ & $31-48 \quad(11$ & $39-47 \quad(92)$ & $127-182(456)$ \\
\hline & $6-9 \quad(59)$ & $16-25 \quad(12$ & & $4-4 \quad(82)$ & $31-47$ \\
\hline & $8-18 \quad(88)$ & & & $7-7 \quad(10$ & $82 \quad(478)$ \\
\hline & $1-3 \quad(72)$ & $14-$ & & & $8 \quad(422$ \\
\hline & & 12 & & 19 & $\begin{array}{ll}0 & (463)\end{array}$ \\
\hline & 44-67 (101) & $85-126(188$ & $70-108(1$ & $42-70(100)$ & $241-371(545)$ \\
\hline & $0-2 \quad(48)$ & $3-6 \quad(72$ & & $1-1 \quad(69)$ & $4-9 \quad(293)$ \\
\hline & (89) & $2-3 \quad(141)$ & & (84) & $6-7 \quad(455)$ \\
\hline UA & $24-42 \quad(89)$ & $64-86 \quad(168)$ & $46-67$ & $38-57 \quad(93)$ & $172-252(460)$ \\
\hline $\mathrm{UZ}$ & $3-5 \quad(77)$ & $11-12 \quad(151)$ & $0-0$ & $5-6 \quad(100)$ & $19-23$ \\
\hline
\end{tabular}

TABLE 1. Products under quality improvement

The first two figures are the number of products under quality improvement in 1993 and 1999, respectively. Numbers in parentheses are total numbers of products traded in a given sector. Data source: International Trade Centre UNCTAD/WTO 


\begin{tabular}{l|rrrc|c} 
Country & $\begin{array}{c}\text { Quality } \\
\text { Comp. }\end{array}$ & $\begin{array}{c}\text { Price } \\
\text { Comp. }\end{array}$ & $\begin{array}{c}\text { Deficit P. } \\
\text { Comp. }\end{array}$ & $\begin{array}{c}\text { Structural } \\
\text { Problems }\end{array}$ & Total \\
\hline BG & 123 & 81 & 166 & 150 & 520 \\
CZ & 152 & 104 & 202 & 165 & 623 \\
EE & 64 & 54 & 137 & 217 & 472 \\
HU & 83 & 106 & 202 & 203 & 594 \\
LV & 59 & 34 & 104 & 246 & 443 \\
LT & 75 & 33 & 120 & 234 & 462 \\
PL & 84 & 65 & 251 & 210 & 610 \\
RO & 127 & 84 & 168 & 164 & 543 \\
SK & 122 & 72 & 175 & 185 & 554 \\
SI & 91 & 79 & 184 & 234 & 588 \\
\hline AM & 7 & 7 & 1 & 313 & 328 \\
AZ & 7 & 9 & 17 & 420 & 453 \\
BY & 79 & 48 & 83 & 246 & 456 \\
GE & 20 & 8 & 26 & 313 & 367 \\
KZ & 34 & 24 & 42 & 378 & 478 \\
KG & 12 & 17 & 16 & 377 & 422 \\
MD & 25 & 25 & 21 & 392 & 463 \\
RU & 133 & 88 & 185 & 139 & 545 \\
TJ & 4 & 7 & 2 & 280 & 293 \\
TM & 3 & 10 & 4 & 438 & 455 \\
UA & 86 & 64 & 137 & 173 & 460 \\
UZ & 13 & 6 & 8 & 443 & 470
\end{tabular}

TABLE 2. Export competitiveness

Data source: International Trade Centre UNCTAD/WTO 


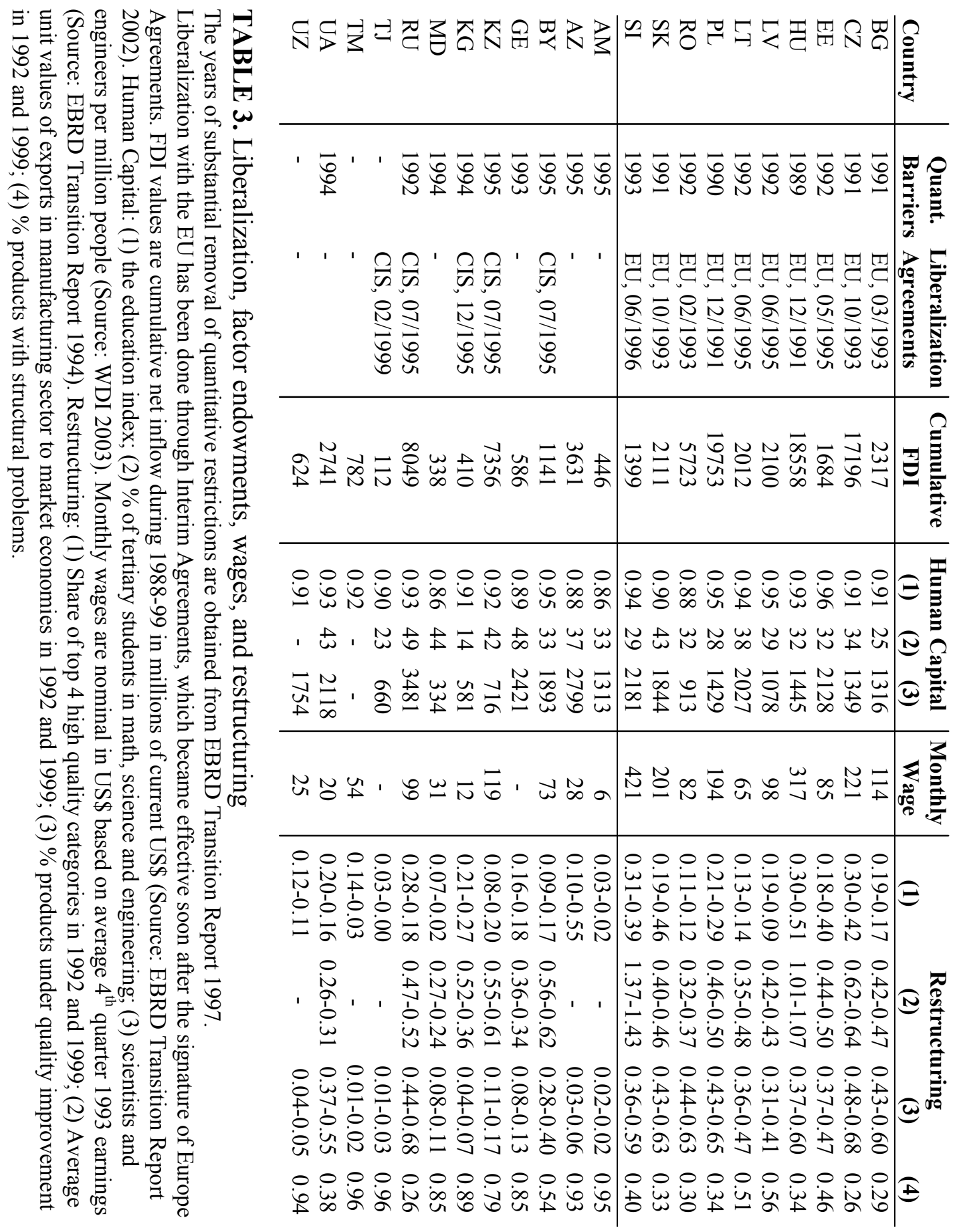




\section{REFERENCES}

Aiginger, Karl, "The use of Unit Value to Discriminate between Price and Quality Competition" Cambridge Journal of Economics 21, 571-92, 1997.

Aiginger, Karl, "Unit Values to Signal the Quality Position of CEECs" In The Competitiveness of Transition Economies, OECD Proceedings, 15-40, 1998.

Bogomolov, Oleg, "The Socialist Countries at a Critical Stage in World Economic Development" Problems of Economics 30, 8:38-54, 1987.

Brenton, Paul, and Gros, Daniel, "Trade Reorientation and Recovery in Transition Economies" Oxford Review of Economic Policy 13, 2:65-6, 1997.

Drabek, Zdenek, and Smith, Alasdair, "Trade Performance and Trade Policy in Central and Eastern Europe” CEPR Discussion Paper 1182, 1995.

Enoch, C. A., "Measures of Competitiveness in International Trade" Bank of England Quarterly Bulletin 18, 181-95, 1978.

Funke, Michael, and Ruhwedel, Ralf, "Export Variety and Export Performance: Empirical Evidence for the OECD Countries" Weltwirtschaftliches Archiv 138, 1:97$114,2002$.

Grossman, Gene, and Helpman, Elhanan, "Quality Ladders and Product Cycles" Quarterly Journal of Economics 106, 2:557-86, 1991.

Hoekman, Bernard, and Djankov, Simeon, "Intra-industry Trade, Foreign Direct Investment, and the Reorientation of Eastern European Exports" World Bank Policy Research Working Paper 1652, Washington DC, 1996.

Hufbauer, Gary, "The Impact of National Characteristics and Technology on the Commodity Composition of Trade in Manufactured Goods" In Vernon, Raymond 
(ed.), The Technology Factor in International Trade, Columbia University Press, New York, 1970.

Hummels, David, and Klenow, Peter, "The Variety and Quality of a Nation's Trade" NBER Working Paper 8712, 2002.

King, Alan, "A Note on Export Unit Value Indices in Competitiveness Variables" Bulletin of Economic Research 45, 1:69-77, 1993.

Kravis, Irving, and Lipsey Robert, Price Competitiveness in World Trade, Columbia University Press, New York, 1971.

Kravis, Irving, and Lipsey Robert, "International Trade Prices and Price Proxies" In Ruggles, Nancy (ed.), The Role of the Computer in Economic and Social Research in Latin America, NBER, New York, pp. 253-68, 1971.

Landesmann, Michael, and Burgstaller, Johann, "Vertical Product Differentiation in EU Markets: The Relative Position of East European Producers" In The Competitiveness of Transition Economies, OECD Proceedings, pp. 123-58, 1998.

Lipsey, Robert, Price and Quantity Trends in the Foreign Trade of the United States, Princeton University Press, Princeton, 1963.

Maciejewski, E. B., "Real Effective Exchange Rate Indexes -a Reexamination of the Major Conceptual and Methodological Issues" IMF Staff Papers 30, 491-541, 1983.

Martin, R., "Central and Eastern Europe and the International Economy: The Limits to Globalization” Europe-Asia Studies 50, 1:7-26, 1998.

Neven, Damien, “Trade Liberalization with Eastern Nations: How Sensitive?" In Faini, Riccardo, and Portes, Richard (eds.), European Union Trade with Eastern Europe: Adjustment and Opportunities, CEPR, London, 1995. 
Prosi, Gerhard, "Economic Cooperation between Members of the European Union and New Democratic Countries of Europe" Communist Economies and Economic Transformation 10, 1:111-18, 1998.

Rosati, Dariusz, "Emerging Trade Patterns of Transition Countries: Some Observations from the Analysis of Unit Values" MOCT-MOST 8, 51-67, 1998.

Sheets, Nathan, and Boata, Simona, "Eastern European Export Performance during the Transition" Contemporary Economic Policy 16, 211-26, 1998.

Stephan, Johannes, "Industrial Specialization and productivity Catch-up in CEECs Patterns and Prospects" Halle Institute for Research, Working Paper 1, 2003.

Treml, Vladimir, "Inferior Quality of Soviet machinery as Reflected in Export Prices" Journal of Comparative Economics 5, 200-21, 1981.

van Brabant, Jan, Socialist Economic Integration, Cambridge University Press, Cambridge, 1980.

van Brabant, Jan, "Production Specialization in the CMEA: Concepts and Empirical Evidence” Journal of Common Market Studies 26, 3:287-315, 1988.

Wolfmayr-Schnitzer, Yvonne, "Trade Performance of CEECs According to Technology Classes" In The Competitiveness of Transition Economics, OECD Proceedings:81-92, 1998. 


\section{APPENDIX 1.}

SITC-3 codes of products in each factor content categories

Resource intensive:

$511,512,513,514,562,611,613,634,635,641,652,653,654,659,661,662,663,664$ $665,666,671,672,673,674,675,676,677,678,681,682,683,684,685,686,687,693$, 694

Human capital intensive-low technology:

$553,554,592,593,711,712,713,716,742,743,762,773,793,898$

Labor intensive:

$612,621,625,629,633,642,651,655,656,657,658,667,692,696,697,699,721,722$, $724,771,784,785,786,791,812,813,821,831,841,842,843,844,845,846,848,851$, $885,891,892,893,894,895,897,898,899$

Human capital intensive-medium technology-labor intensive: $689,691,695,723,725,726,727,728,731,733,735,737,741,744,745,746,747,748$, $749,751,759,761,763,764,772,774,775,811,872,873,881,884$

Human capital intensive-medium technology-capital intensive:

$515,522,523,524,531,532,533,551,571,572,573,574,575,579,581,582,583,597$, $598,679,781,782,783,882$

Human capital intensive-high technology-labor intensive:

$714,718,776,778,792,871,874$

Human capital intensive-high technology-capital intensive:

$516,525,541,542,591,752$ 
${ }^{1}$ Interim Agreements on trade with the EU became effective by 1991, in Hungary (HU), and Poland (PL), 1993 with Bulgaria (BG), the Czech Republic (CZ), Romania (RO), and the Slovak Republic (SK), and by the end of 1996 in Slovenia (SI), Estonia (EE), Latvia (LV), and Lithuania (LT). The Russian Federation (RU), Kazakhstan (KZ), Belarus (BY) formed the CIS customs union in 1995. Kyrgyzstan (KG) and Tajikistan (TJ) joined in by the end of 1995, and 1999, respectively. Other CIS countries, Armenia (AM), Azerbaijan (AZ), Georgia (GE), Moldova (MD), Turkmenistan (TM), Ukraine (UA), and Uzbekistan (UZ) did not participate in the customs union.

${ }^{2}$ These constitute the most important developed and developing partners with market economies: Austria, Belgium, Brazil, Canada, China, Denmark, Egypt, Finland, France, Germany, Greece, Hong Kong, Indonesia, Italy, Japan, Korea, Luxembourg, the Netherlands, Norway, Portugal, Philippines, Singapore, Spain, Sweden, Switzerland, Thailand, Turkey, the UK, and the US. Exports to these countries constitute $97.3 \%$ of transition exports to all market economies in the world.

${ }^{3}$ Share of market economies in transition countries' manufacturing exports varies between 76 to $90 \%$.

${ }^{4}$ In a relevant earlier research, Neven (1995) finds that CEEC exports to the EU were concentrated on products that were intensive in relatively unskilled labor during 19851990.

${ }^{5}$ Using a similar idea, Sheets and Boata (1998) take the extent of reorientation of trade from CMEA to the EU as a sign of restructuring: To the extent that industrial restructuring has taken place, the decline in CMEA exports should be related to expansion of exports to the EU with a lag, time needed to restructure. Price competition 
implies that decline in CMEA exports and increase in EU exports should be roughly contemporaneous.

${ }^{6}$ Products categories that transition countries were importing but unable to export are included in the group of traded products.

${ }^{7}$ The initial low proportion of products under quality improvement in relatively richer Slovenia and Hungary is most likely due to the fact that most products in these two countries were already of high quality, and not much further improvement was needed.

${ }^{8}$ Products categories that transition countries were importing but unable to export are assumed to have structural problems.

${ }^{9}$ In a relevant research, Stephan (2003) found the level of productivity in most advanced 6 CEEC to increase from $22-55 \%$ of the EU average in 1993 to $46-76 \%$ in 2000. 


\section{DAVIDSON INSTITUTE WORKING PAPER SERIES - Most Recent Papers}

The entire Working Paper Series may be downloaded free of charge at: www.wdi.bus.umich.edu

CURRENT AS OF $1 / 13 / 04$

\begin{tabular}{|c|c|c|}
\hline Publication & Authors & Date \\
\hline $\begin{array}{l}\text { No. 638: The Politics of Economic Reform in Thailand: Crisis and } \\
\text { Compromise }\end{array}$ & Allen Hicken & Jan. 2004 \\
\hline $\begin{array}{l}\text { No. 637: How Much Restructuring did the Transition Countries } \\
\text { Experience? Evidence from Quality of their Exports }\end{array}$ & Yener Kandogan & Jan. 2004 \\
\hline $\begin{array}{l}\text { No. 636: Estimating the Size and Growth of Unrecorded Economic } \\
\text { Activity in Transition Countries: A Re-Evaluation of Eclectric } \\
\text { Consumption Method Estimates and their Implications }\end{array}$ & Edgar L. Feige and Ivana Urban & Dec. 2003 \\
\hline No. 635: Measuring the Value Added by Money & Vlad Ivanenko & Nov. 2003 \\
\hline $\begin{array}{l}\text { No. 634: Sensitivity of the Exporting Economy on the External Shocks: } \\
\text { Evidence from Slovene Firms }\end{array}$ & $\begin{array}{l}\text { Janez Prašnikar, Velimir Bole, } \\
\text { Aleš Ahcan and Matjaž Koman }\end{array}$ & Nov. 2003 \\
\hline $\begin{array}{l}\text { No. 633: Reputation Flows: Contractual Disputes and the Channels for } \\
\text { Inter-firm Communication }\end{array}$ & William Pyle & Nov. 2003 \\
\hline $\begin{array}{l}\text { No. 632: The Politics of Development Policy and Development Policy } \\
\text { Reform in New Order Indonesia }\end{array}$ & Michael T. Rock & Nov. 2003 \\
\hline $\begin{array}{l}\text { No. 631: The Reorientation of Transition Countries' Exports: } \\
\text { Changes in Quantity, Quality and Variety }\end{array}$ & Yener Kandogan & Nov. 2003 \\
\hline $\begin{array}{l}\text { No. 630: Inequality of Outcomes and Inequality of Opportunities in } \\
\text { Brazil }\end{array}$ & $\begin{array}{l}\text { François Bourguignon, Francisco } \\
\text { H.G. Ferreira and Marta } \\
\text { Menéndez }\end{array}$ & Nov. 2003 \\
\hline No. 629: Job Search Behavior of Unemployed in Russia & Natalia Smirnova & Nov. 2003 \\
\hline $\begin{array}{l}\text { No. 628: How has Economic Restructuring Affected China's Urban } \\
\text { Workers? }\end{array}$ & John Giles, Albert Park, Feng Cai & Oct. 2003 \\
\hline No. 627: The Life Cycle of Government Ownership & Jiahua Che & Oct. 2003 \\
\hline $\begin{array}{l}\text { No. 626: Blocked Transition And Post-Socialist Transformation: Siberia } \\
\text { in the Nineties }\end{array}$ & Silvano Bolcic & Oct. 2003 \\
\hline $\begin{array}{l}\text { No. 625: Generalizing the Causal Effect of Fertility on Female Labor } \\
\text { Supply }\end{array}$ & $\begin{array}{l}\text { Guillermo Cruces and Sebastian } \\
\text { Galiani }\end{array}$ & Oct. 2003 \\
\hline $\begin{array}{l}\text { No. 624: The Allocation and Monitoring Role of Capital Markets: } \\
\text { Theory and International Evidence }\end{array}$ & Solomon Tadesse & Oct. 2003 \\
\hline No. 623: Firm-Specific Variation and Openness in Emerging Markets & $\begin{array}{l}\text { Kan Li, Randall Morck, Fan Yang } \\
\text { and Bernard Yeung }\end{array}$ & Oct. 2003 \\
\hline $\begin{array}{l}\text { No. 622: Exchange Rate Regimes and Volatility: Comparison of the } \\
\text { Snake and Visegrad }\end{array}$ & $\begin{array}{l}\text { Juraj Valachy and Evžen } \\
\text { Kočenda }\end{array}$ & Oct. 2003 \\
\hline $\begin{array}{l}\text { No. 621: Do Market Pressures Induce Economic Efficiency?: The Case } \\
\text { of Slovenian Manufacturing, 1994-2001 }\end{array}$ & $\begin{array}{l}\text { Peter F. Orazem and Milan } \\
\text { Vodopivec }\end{array}$ & Oct. 2003 \\
\hline $\begin{array}{l}\text { No. 620: Compensating Differentials in Emerging Labor and Housing } \\
\text { Markets: Estimates of Quality of Life in Russian Cities }\end{array}$ & $\begin{array}{l}\text { Mark C. Berger, Glenn C. } \\
\text { Blomquist and Klara Sabirianova } \\
\text { Peter }\end{array}$ & Oct. 2003 \\
\hline $\begin{array}{l}\text { No. 619: Are Foreign Banks Bad for Development Even If They Are } \\
\text { Efficient? Evidence from the Indian Banking Sector }\end{array}$ & $\begin{array}{l}\text { Sumon Bhaumik and Jenifer } \\
\text { Piesse }\end{array}$ & Oct. 2003 \\
\hline No. 618: The Echo of Job Displacement & $\begin{array}{l}\text { Marcus Eliason and Donald } \\
\text { Storrie }\end{array}$ & Oct. 2003 \\
\hline No. 617: Deposit Insurance During Accession EU Accession & $\begin{array}{l}\text { Nikolay Nenovsky and Kalina } \\
\text { Dimitrova }\end{array}$ & Oct. 2003 \\
\hline $\begin{array}{l}\text { No. 616: Skill-Biased Transition: The Role of Markets, Institutions, and } \\
\text { Technological Change }\end{array}$ & Klara Sabirianova Peter & Oct. 2003 \\
\hline $\begin{array}{l}\text { No. 615: Initial Conditions, Institutional Dynamics and Economic } \\
\text { Performance: Evidence from the American States }\end{array}$ & Daniel Berkowitz and Karen Clay & Sept. 2003 \\
\hline $\begin{array}{l}\text { No. 614: Labor Market Dynamics and Wage Losses of Displaced } \\
\text { Workers in France and the United States }\end{array}$ & Arnaud Lefranc & Sept. 2003 \\
\hline No. 613: Firm Size Distribution and EPL in Italy & $\begin{array}{l}\text { Fabiano Schivardi and Roberto } \\
\text { Torrini }\end{array}$ & Sept. 2003 \\
\hline
\end{tabular}

